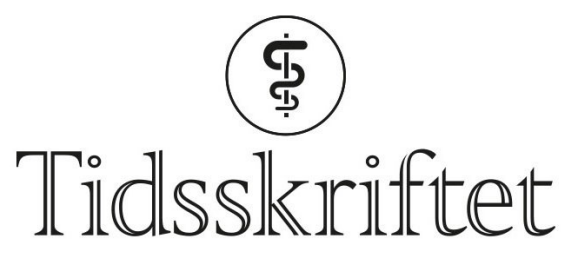

DEN NORSKE LEGEFORENING

\title{
Overdiagnostikk av demens?
}

KOMMENTAR

\section{EIRIK HORNES HALVORSEN}

E-post: eirhal@siv.no

Eirik Hornes Halvorsen er overlege ved Radiologisk avdeling, Sykehuset i Vestfold. Ingen oppgitte interessekonflikter.

I en artikkel i Tidsskriftet ble det beskrevet en mann med hemosiderinavleiring i hjernen (1). Man får i denne artikkelen inntrykk av at CT thorax, abdomen og bekken inngår i utredningen av demens hos en pasient i go-årene med tidligere hjerneblødning. Videre beskrives at man også har gjort CT caput, spinalpunksjon, EEG og MR caput i utredningen, og funnet både Alzheimers sykdom og hemosiderose. De spesifikke betraktningene rundt Creutzfeldt-Jakobs sykdom gir inntrykk av at denne sjeldne tilstanden særlig ble vurdert som differensialdiagnose og årsak til pasientens sykehistorie.

Etter min mening framstår dette samlet som overdiagnostikk og i overkant «flinkt». Ukritisk overforbruk av bildediagnostikk og prøvetakning som en del av «brede» utredninger er et stort problem i dag, og vil bli et enda større problem framover dersom demensutredning hos pasienter i go-årene skal gjøres som beskrevet her. Creutzfeldt-Jakobs sykdom bør neppe være det første man tenker på som årsak til denne sykehistorien. Realisme, edruelighet og riktig ressursbruk etterlyses.

LITTERATUR:

1. Schüler SJ, Kvistad KA. Hemosiderinavleiringer i hjernen. Tidsskr Nor Legeforen 2017; 137: 1051.

Publisert: 2. oktober 2017. Tidsskr Nor Legeforen. DOI: 10.4045/tidsskr.17.0777

(C) Tidsskrift for Den norske legeforening 2020. Lastet ned fra tidsskriftet.no 